\title{
"Hot Water" in Lassen Volcanic National Park- Fumaroles, Steaming Ground, and Boiling Mudpots
}

Hydrothermal (hot water)
features at Lassen Volcanic
National Park fascinate
visitors to this region of
northeastern California.
Boiling mudpots, steaming
ground, roaring fumaroles,
and sulfurous gases are linked
to active volcanism and are
all reminders of the ongoing
potential for eruptions in
the Lassen area. Nowhere
else in the Cascade Range of
volcanoes can such an array of
hydrothermal features be seen.
Recent work by scientists with
the U.S. Geological Survey
(USGS), in cooperation with
the National Park Service,
is shedding new light on the
inner workings of the Lassen
hydrothermal system.

The remarkable hydrothermal features in Lassen Volcanic National Park include roaring fumaroles (steam and volcanic-gas vents), thumping mudpots, boiling pools,

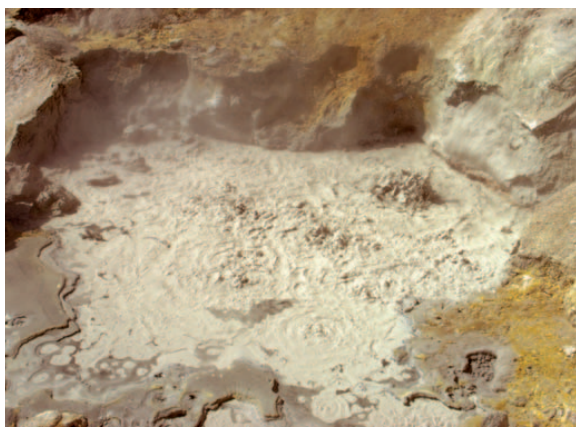

The vigor of Lassen's hydrothermal features, such as this mudpot, varies seasonally. In spring, when cool ground water from snowmelt is abundant, fumaroles and pools have lower temperatures, and the mud in mudpots is more fluid.

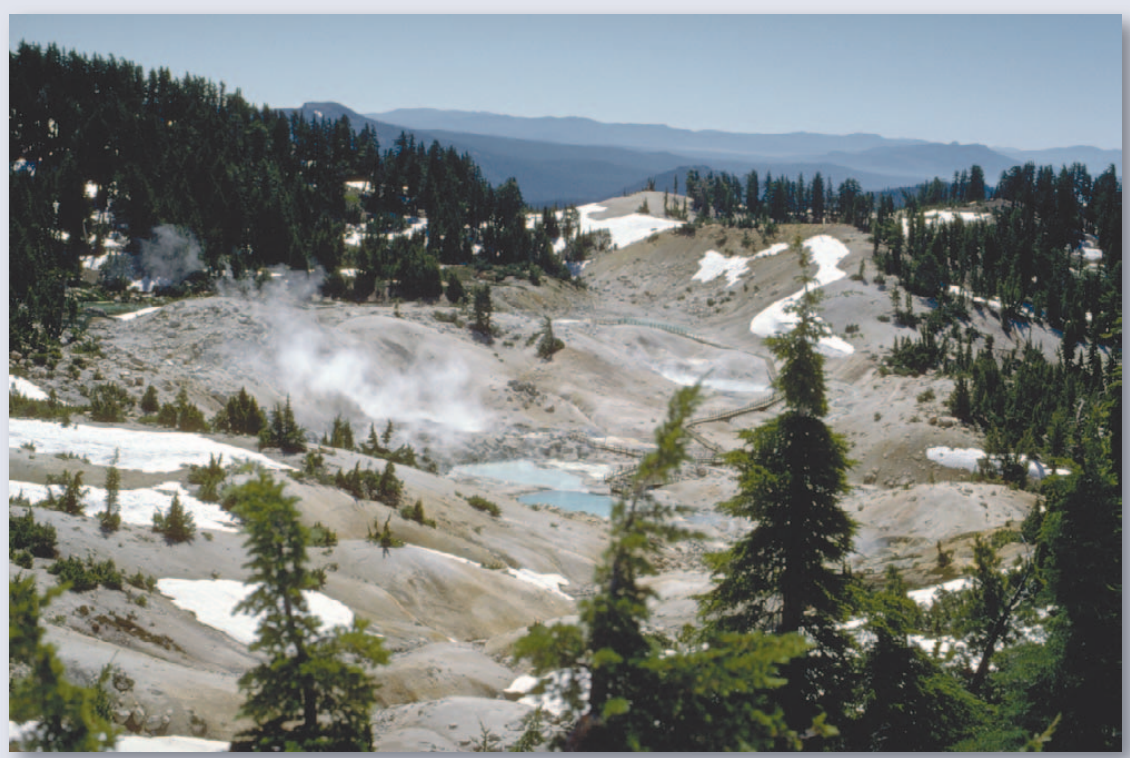

The hottest and most vigorous hydrothermal features in Lassen Volcanic National Park are at Bumpass Hell, which marks the principal area of upflow and steam discharge from the Lassen hydrothermal system. A prominent steam plume marks the site of Big Boiler, the largest fumarole (steam and volcanic-gas vent) in the park. The temperature of the high-velocity steam jetting from it has been measured as high as $322^{\circ} \mathrm{F}$ $\left(161^{\circ} \mathrm{C}\right)$. Most of the hydrothermal features in the park contain mixtures of condensed steam and near-surface ground water and have temperatures that are near boiling. The steam-heated waters of the features are typically acidic and, even if cool enough, are not safe for bathing.

and steaming ground. These features are related to active volcanism and are indications of the ongoing potential for further eruptions from the Lassen "volcanic center."

The Lassen region is at the south end of the Cascade chain of volcanoes and at the west edge of the Basin and Range Province. The volcanoes of the Cascade Range are created by rising molten rock (magma). This magma is generated as the oceanic Juan de Fuca Plate, one of the tectonic plates making up the Earth's outer shell, plunges (is "subducted") beneath the continental North American Plate. The boundary between these plates, called the Cascadia Subduction Zone, dips eastward beneath the Pacific Northwest at an offshore trench. The geology of the Lassen region is also influenced by horizontal extension (stretching) of the Earth's crust in the Basin and Range Province, just to the east.

Nearly all of the volcanic rocks in the Lassen region were erupted within the past 3 million years. Volcanic activity at the Lassen volcanic center began with the formation of the Brokeoff stratovolcano about 600,000 years ago. More recent activity created Lassen Peak, a volcanic dome emplaced about 27,000 years ago; Chaos Crags, a dome complex formed about 1,100 years ago; and Cinder Cone, which erupted about 350 years ago. The latest eruptions in the area occurred during 1914-17 at Lassen Peak.

\section{Hydrothermal Features}

The areas of hydrothermal activity in Lassen Volcanic National Park include Bumpass Hell, Little Hot Springs Valley, Pilot Pinnacle, Sulphur Works, Devils Kitchen, Boiling 


\section{THE LASSEN HYDROTHERMAL SYSTEM}

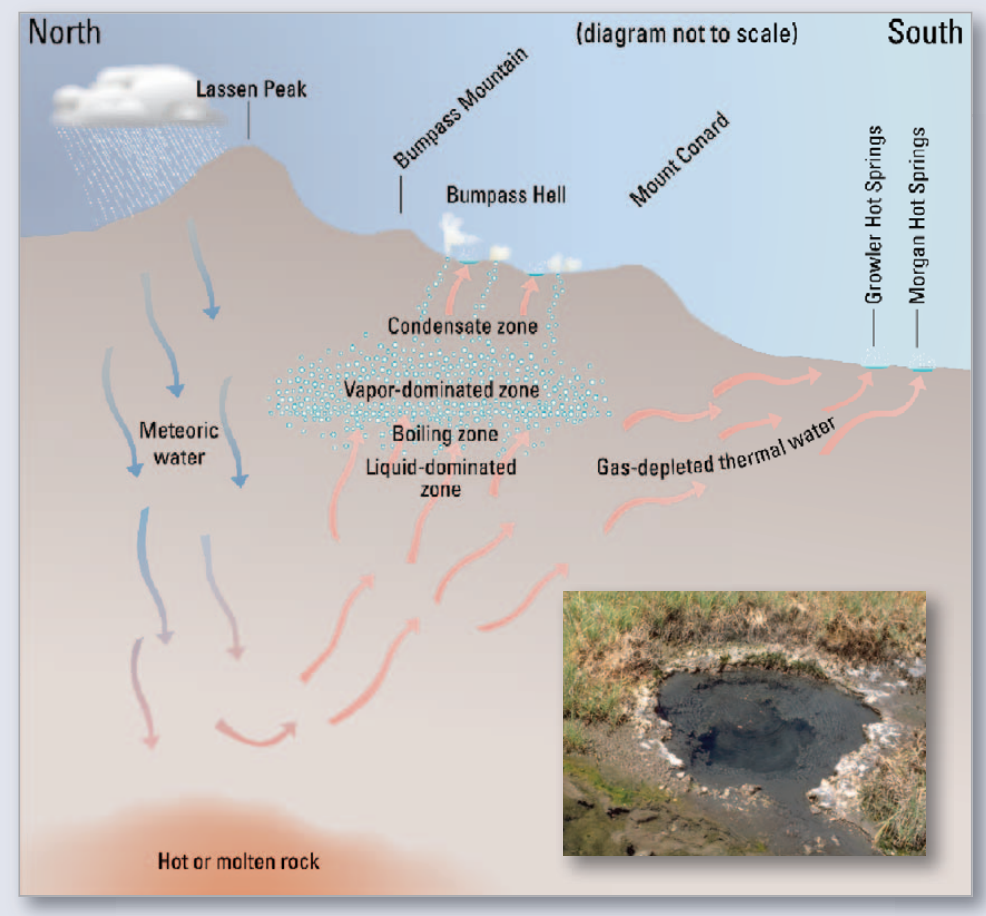

Water from rain and snow (meteoric water) that falls on the highlands of Lassen Volcanic National Park feeds the Lassen hydrothermal system. Once deep underground, the water is heated by a body of hot or molten rock beneath Lassen Peak. The deeper part of the system, where hot water saturates the rock, is called the liquid-dominated zone. At shallower depths, lower pressure allows rising hot water to boil. The subsurface area in which steam and gas prevail in open fractures is called the vapor-dominated zone. Although most of the steam condenses near the surface, some reaches the surface through conduits to form fumaroles (steam and volcanic-gas vents), such as those at Bumpass Hell. Additionally, beneath the surface, gasdepleted hot water flows away from the liquid-dominated zone and reaches the surface south of the Park to form hot springs, such as Morgan Hot Springs (inset photo).

elevations. The steamheated waters are typically acidic and are not safe, even for bathing, except at Drakesbad Guest Ranch.

The vigor of Lassen's hydrothermal features varies both seasonally and from year to year. In spring, when cool ground water from snowmelt is abundant, the fumaroles and pools have lower temperatures, and the mud in mudpots is more fluid. In late summer and in drought years, the features become drier and hotter because there is less mixing with shallow, cool ground water. On a longer time scale, hydrothermal features may shift position, die out, or evolve into different types

Springs Lake, and Terminal Geyser, which is not a true geyser but the result of a cold stream flowing over a steam vent. Related features also occur south of the park in Mill Canyon at Morgan and Growler Hot Springs.

All the features in the park are driven by steam generated by boiling of an underground reservoir of hot water. The hottest and most vigorous features are at Bumpass Hell, which marks the principal area of upflow and steam discharge from the Lassen hydrothermal system. The temperature of high-velocity steam jetting from Big Boiler, the largest fumarole in the park, has been measured as high as $322^{\circ} \mathrm{F}\left(161^{\circ} \mathrm{C}\right)$, making it one of the hottest hydrothermal fumaroles in the world. Most of the hydrothermal features contain mixtures of condensed steam and near-surface ground water and have temperatures that are near the boiling point of water at their respective of features. For example, an area of steaming ground in upper Sulphur Works collapsed in the early 1980's to form a huge, boiling mudpot. To protect visitors and also to understand the origin and evolution of such features, National Park Service (NPS) personnel and scientists with the U.S.

Geological Survey (USGS) continuously monitor the physical and chemical characteristics of surface hydrothermal activity in Lassen Volcanic National Park.
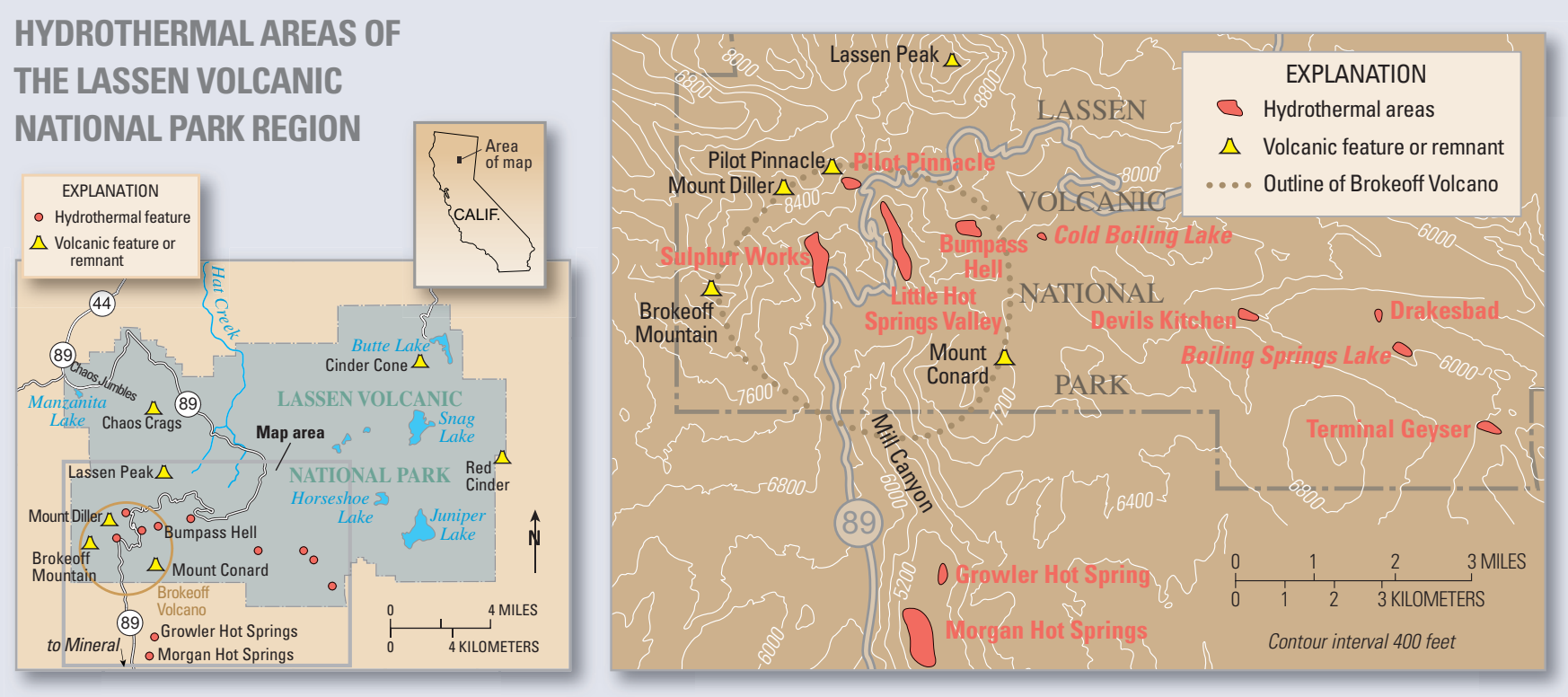


\section{BROKEOFF MOUNTAIN AND HYDROTHERMAL ALTERATION}
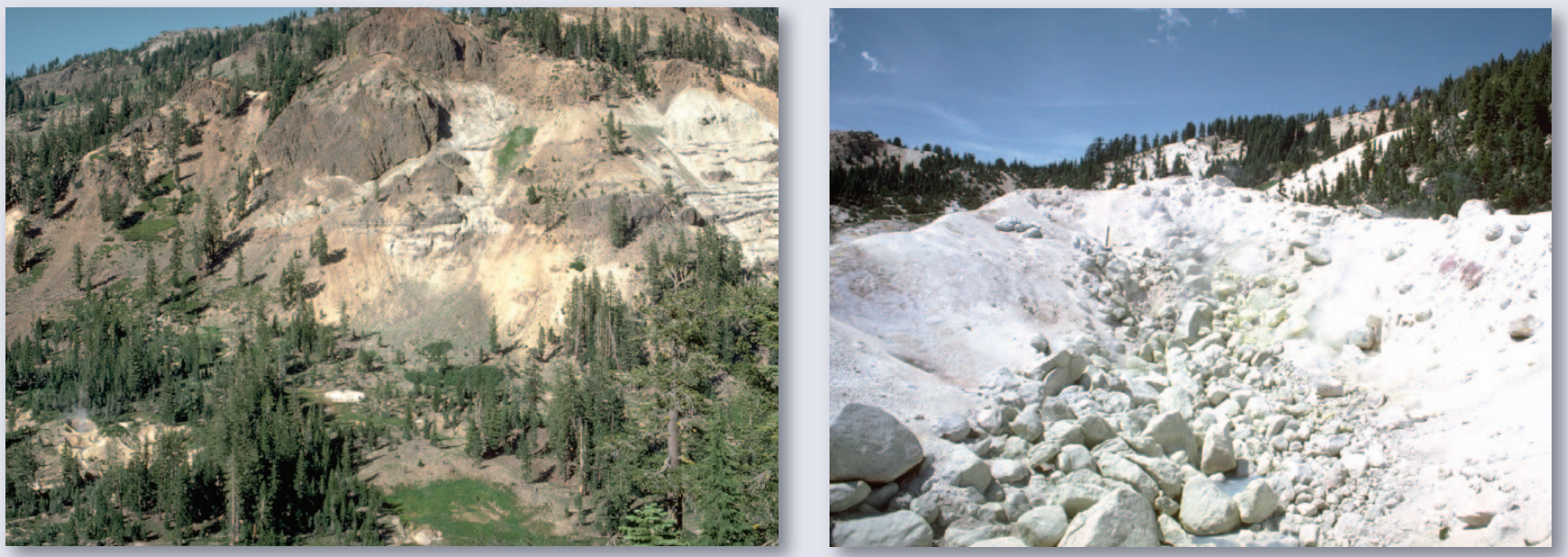

Volcanic activity at the Lassen volcanic center began with the formation of "Brokeoff" stratovolcano (also called Mount Tehama) about 600,000 years ago. A drive through the exposed interior of the old Brokeoff Volcano, along Highway 89 in Lassen Volcanic National Park, provides dramatic views (left) of yellowbrown altered rocks, evidence that a hydrothermal system has been active throughout the volcano. Hydrothermal alteration occurs when acidic hot water chemically changes minerals in rocks. The end product of such alteration in volcanic rocks is a white material rich in kaolinite clay and silica; this material is abundant at Bumpass Hell (right). The alteration process weakens rocks, making them more susceptible to erosion. Over time, a substantial part of Brokeoff Volcano was removed by erosion, leaving remnants that include today's Brokeoff Mountain, Mount Diller, and Mount Conard. The thermal areas of Sulphur Works and Little Hot Springs Valley are within the depression left by this erosion. The focus of hydrothermal activity and alteration shifts with time as the underground plumbing changes and pathways of fluid flow are sealed by mineral deposition or fractured by earthquakes.

\section{The Origin of the Lassen Hydrothermal System}

Steam vents and hot springs are surface expressions of hydrothermal systems, in which cold surface water percolates deep into the ground, where it is warmed by the slow release of thermal energy from a heat source. The Lassen volcanic center is host to such a system because it has the three required elements - abundant ground water, permeable rock, and a heat source at depth.

The water that supplies the Lassen hydrothermal system comes from rain and snow that falls on the highlands of Lassen Volcanic National Park. This water enters the ground through permeable rock and along favorable pathways, such as fractures and faults in rock or boundaries between volcanic flows. Once deep underground, the water is heated. The heat source is a body of magma or a body of solid but still very hot rock related to recent volcanism. This heat source is probably located at a depth of 5 to 6 miles $(8-10 \mathrm{~km})$ beneath Lassen Peak.

When water penetrates the hot rock surrounding the heat source, it is heated by conduction. Hydrochloric acid, sulfurous gases, and other volatiles emitted by the body of magma or hot rock dissolve in the water as it is heated. Because it is less dense than cold water, the heated water rises by convection. As the water rises, acids react with surrounding rock, enriching the water in dissolved silica $\left(\mathrm{SiO}_{2}\right)$ and metals. The chemically evolving hot water rises to a depth of about half a mile to a mile (1-2 km) below the surface, where it saturates permeable rock and accumulates in fractures beneath the thermal features in Lassen Volcanic National Park. This reservoir of hot water in the deeper part of the hydrothermal system is called the liquid-dominated zone. Using analyses of the chemical composition of gases from the highest-temperature fumaroles in the park, USGS scientists calculate that the temperature of this part of the Lassen hydrothermal system is 455 to $464^{\circ} \mathrm{F}\left(235-240^{\circ} \mathrm{C}\right)$.

When rising hot water reaches a depth of about half a mile $(1 \mathrm{~km})$, where the pressure of overlying fluid (hydrostatic pressure) has decreased to about 30 times atmospheric pressure, boiling occurs. Bubbles of steam rise through the water and migrate to the surface, carrying most of the gases that were dissolved in the water (carbon dioxide, hydrogen sulfide, hydrogen, nitrogen, and helium). The subsurface zone in which steam and gas prevail in open fractures is called the vapor-dominated zone.

Steam from the Lassen hydrothermal system reaches the surface through conduits to form high-temperature fumaroles. It may also condense and heat ground water near the surface. This condensed steam and heated water may boil at the water table, creating areas of steaming ground or surface features such as boiling mudpots and sizzling

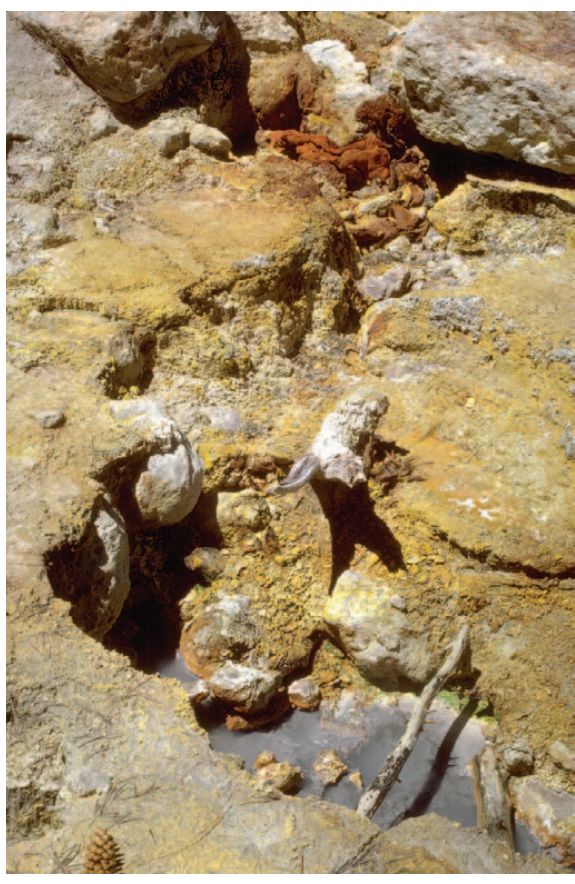

In active hydrothermal areas, hot water enriched in dissolved metals and other chemicals evaporates. This leaves behind colorful sulfate minerals like the yellow copiapite (hydrous iron sulfate) and black or brassy pyrite (iron sulfide or fool's gold) seen here at Devils Kitchen. 


\section{LIFE IN THE HOT SPRINGS}
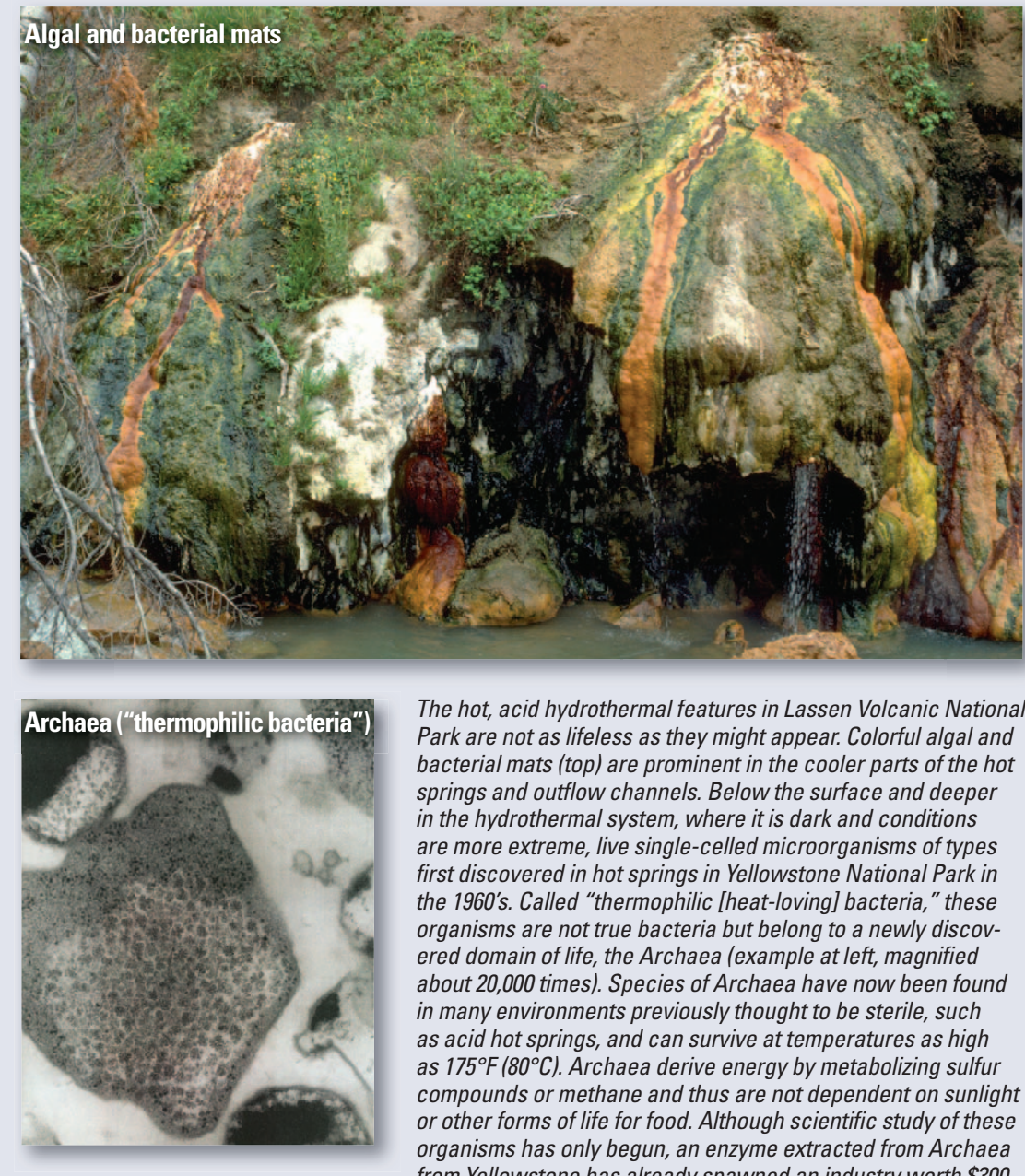

The hot, acid hydrothermal features in Lassen Volcanic National Park are not as lifeless as they might appear. Colorful algal and bacterial mats (top) are prominent in the cooler parts of the hot springs and outflow channels. Below the surface and deeper in the hydrothermal system, where it is dark and conditions are more extreme, live single-celled microorganisms of types first discovered in hot springs in Yellowstone National Park in the 1960's. Called "thermophilic [heat-loving] bacteria," these organisms are not true bacteria but belong to a newly discovered domain of life, the Archaea (example at left, magnified about 20,000 times). Species of Archaea have now been found in many environments previously thought to be sterile, such as acid hot springs, and can survive at temperatures as high as $175^{\circ} \mathrm{F}\left(80^{\circ} \mathrm{C}\right)$. Archaea derive energy by metabolizing sulfur compounds or methane and thus are not dependent on sunlight or other forms of life for food. Although scientific study of these organisms has only begun, an enzyme extracted from Archaea from Yellowstone has already spawned an industry worth $\$ 300$ million dollars a year. Studies also suggest that life on Earth may have sprung from microbes similar to modern Archaea that were born in undersea hot springs at least 3.5 billion years ago. Similar environments may have been a cradle for life on other planetary bodies, such as Mars and Jupiter's moon Europa.

"frying pans" (shallow, vigorously boiling pools of clear water). Hydrogen sulfide gas (the gas that makes rotten eggs smell) is oxidized in this near-surface, oxygen-rich environment to form elemental sulfur and sulfuric acid, producing waters that are acidic (low $\mathrm{pH}$ ) and have a high sulfate concentration. Waters rich in bicarbonate $\left(\mathrm{HCO}_{3}^{-}\right)$ occur at the margins of steam-heated areas, where steam and carbon dioxide $\left(\mathrm{CO}_{2}\right)$ from the underlying vapor-dominated zone are condensed into poorly oxygenated ground water and emerge as warm springs that deposit travertine (calcium carbonate).

As steam rises to feed the higher elevation thermal features in Lassen Volcanic National Park, gas-depleted hot water flows laterally from the underground reservoir along permeable pathways and reaches the surface south of the park at lower elevations (about 5,000 feet or $1,500 \mathrm{~m}$ ). The gas-depleted, high-chloride, neutral-pH waters of Growler and Morgan Hot Springs, along Mill Creek, are fed by such lateral outflow from the principal liquid plume that boils beneath the south flank of Lassen Peak. Measured temperatures of these hot springs range from 126 to $207^{\circ} \mathrm{F}\left(52-97^{\circ} \mathrm{C}\right)$. The boiling point of water at the elevations of these springs is about $203^{\circ} \mathrm{F}\left(95^{\circ} \mathrm{C}\right)$. Growler Hot Spring has the highest temperature and the highest chloride content of these features. Highchloride hot water has also been found at depth beneath Terminal Geyser, inside the park. Additional outflow of water derived from the Lassen hydrothermal system, much diluted by mixing with cold ground water, occurs at Domingo Springs and by seepage into several streams that drain the Lassen region toward the south.

The steam features within Lassen Volcanic National Park are directly related to the hot springs and thermal waters that discharge outside of the south park boundary. Both the steam and the high-chloride water are supplied by the same high-temperature fluid plume that ascends and boils within the park. This plume is part of a hydrothermal circulation system that has a single heat source. Evaluation of these hydrologic connections by USGS scientists indicates that geothermal development within the Lassen Known Geothermal Resource Area, south of the park, would affect the hydrothermal features within the park. To help ensure that these remarkable features can continue to be enjoyed, the U.S. Forest Service has established a buffer zone south of the park, in Lassen National Forest, where no geothermal energy production should take place.

The work of USGS scientists investigating the Lassen hydrothermal system, in cooperation with the NPS, is helping to shed new light on volcano hazards in the region of Lassen Volcanic National Park. The work of these scientists is only part of the USGS Volcano Hazards Program's ongoing efforts to protect people's lives and property in all of the volcanic regions of the United States, including Alaska, Hawaii, California, Wyoming, and the Pacific Northwest.

Michael A. Clynne, Cathy J. Janik, and L.J.P. Muffler

Edited by Peter H. Stauffer and James W. Hendley II Graphic design by Sara Boore and Susan Mayfield Banner design by Bobbie Myers

COOPERATING ORGANIZATIONS

Lassen Park Foundation

National Park Service

U.S. Forest Service

$$
\begin{gathered}
\text { For more information contact: } \\
\text { Lassen Volcanic National Park } \\
\text { P.O. Box 100, Mineral, CA } 96063 \\
\text { (530) 595-4444 } \\
\text { http://www.nps.gov/lavo/ } \\
\text { or }
\end{gathered}
$$

http://volcanoes.usgs.gov/

See also Eruptions of Lassen Peak, California, 1914 to 1917 (USGS Fact Sheet 173-98), Volcano Hazards of the Lassen Volcanic National Park Area, California (USGS Fact Sheet 022-00), How Old is "Cinder Cone"?-Solving a Mystery in Lassen Volcanic National Park, California (USGS Fact Sheet 023-00), and Pictorial History of the Lassen Volcano by Benjamin Franklin Loomis (1926, republished by the Lassen Loomis Museum Association).

This Fact Sheet and any updates to it are available online at http://geopubs.wr.usgs.gov/fact-sheet/fs101-02/ 